\title{
Successful Marketing Mode of International Exhibition: Taiwanese Sports Industry
}

\author{
Yen-Hui Lin ${ }^{1}$, Yi-Ju Wang ${ }^{2}$, Kai Cheng ${ }^{3}$, Chih-Yang Chao ${ }^{4}$ \\ ${ }^{1}$ Department of Human Resource Management, National Changhua University of Education, \\ No.2, Shi-Da Road, Changhua County 50074, Taiwan ROC \\ ${ }^{2}$ Department of Business Administration, Overseas Chinese University, 100, Chiao Kwang Rd., Taichung 40721, Taiwan ROC \\ ${ }^{3}$ Department of International Trade, Overseas Chinese University, 100, Chiao Kwang Rd., Taichung 40721, Taiwan ROC \\ ${ }^{4}$ Department of Industrial Education and Technology, National Changhua University of Education, \\ No.2, Shi-Da Road, Changhua County 50074, Taiwan ROC
}

\begin{abstract}
To expand business at international markets, sporting gear producers try to set their products apart with three high, three grand, and three excellent features in the product exhibitions. How to maximize the marketing effectiveness the sporting gear producers adopt when they attend international product exhibitions is the major motivation in this study. The purpose of this article is to explore Taiwan's sport industry that is a successful in marketing design models of the international exhibition. This study explores how Taiwan-based sporting device producers successfully use international exhibitions to maximize their marketing effectiveness. Four Taiwan based popular sporting device producers are included as the subjects. On-site observation and interview were conducted to gather data for analysis. Seven propositions are developed based on literature review. The results provide the academic research and the sport industry in practice operation in future. The main findings of this study are as follows: First, to secure customers' satisfaction about products and on-site marketers, on-site marketers must be furnished with well-rounded on-job training. Second, the location of the exhibition booth is a key factor for the success of the product promotion. Three, if the exhibition provides customers with an experiential activity, the activity will facilitate the communication with the buyer and increase the buyer's reliability about the product. Fourth, a company's publicity is one of the key draws which attract visitors. Fifth, new product is the main goal of participating buyers and customers. Sixth, companies elaborately highlight their corporate identity in planning exhibitions and designing booths. Seventh, looking for new customers is a goal companies try to reach while they take part in a business exhibition.
\end{abstract}

Keywords: Exhibition, International Marking, Sports Industry, Taiwan

\section{Introduction}

MICE (Meeting, Incentive, Convention, Exhibition) is a service industry elaborately coordinating trading, transportation, finance and travel. MICE helps boost economy (Spiller, 2002; Yang \& Gu, 2012) with 3 High (high growth potential, high addition value, high innovation advantage), 3 Grand (grand additional value, grand job opportunity, grand industry association), and 3 Excellence (excellence hummer, excellence technology, excellence efficiency fund). The statistics of ICCA (International Congress \& Convention Association) show that around 400,000 conventions and exhibitions are held across the world annually, at revenue of US\$280 billion. UFI (Union of international Fairs) also indicates that MICE annually generates a business revenue of US $\$ 1,160$ billion, US\$760 billion out of which is brought in by exhibitions. The host nation or city of this business practice can earn sizable profits. Taiwan's economy depends mostly on exports. Taipei World Trade Center does foster the development of MICE.

With the introduction of new technology and the influx of foreign orders, Taiwan has become one of the world's great sporting goods producers and exporters since the 1970s. The business of sporting goods reached its peak in the late 1980s, with some local brands spreading their markets beyond Taiwan. To accumulate valuable experience, advanced manufacturing techniques, high quality and innovation have been injected in this business. In recent years, Taiwan's sporting goods producers endeavor to expand international markets by displaying their latest products and the newest techniques used at international business exhibitions, where more orders are placed by international buyers due to face-to-face communication. What's more, the displays at international exhibitions also boost corporate identity and brand building.

Besides, inspired by some athletes' remarkable performances at international events and the world's growing craze of fitness, an increasing number of people have been picking up exercise on a regular basis. The campaign held by the government to promote exercise and recreation also greatly contributes to the booming of sporting goods businesses. This study explores how sporting goods producers elaborate their displays at international exhibitions to maximize their marketing effectiveness. The findings can be used as references for business practices as well as future academic research

\section{Literature Review}

\subsection{Exhibitions and consumers}

The MICE is organized for business companies to display their products or services in order to attract visitors for trade growth and that the typical of MICE includes meetings, incentives, conventions, and exhibitions (Blythe, 2010; Yang $\&$ Lin, 2015). At an exhibition, producers and suppliers are 


\section{International Journal of Science and Research (IJSR) \\ ISSN (Online): 2319-7064}

Index Copernicus Value (2013): 6.14 | Impact Factor (2015): 6.391

brought together to display their products and services (Rutherford, 1990; Chou \& William, 2013). That is to say, at a particular period of time, an exhibition organizer provides related businesses with an adequate environment to release new products (Holloway et al., 2009), introduce and promote products, and meet buyers face-to-face to boost partnership. This exhibition also offers a chance to businesses to directly contact top executives and boom their business instantly (Czinkota \& Ronkainen, 1988). A business company makes sales and more. It also collects information about contenders, customers, industry trend, and products at the market, boosts corporate identity and brand image, creates a platform for interaction between staff and customers, and strengthen a bond with old and new customers (Hasen, 1999). However, the participating companies at a particular exhibition want to release new products, train staff members, boost publicity, look for business opportunity, obtain orders, and more (Cavanaugh, 1976; Jackson, Keith, \& Burdick, 1987; Yang, \& Lin, 2015).

\subsection{Exhibitions and marketing strategies}

Exhibitions offer producers/suppliers an opportunity of face-to-face chat and communication with consumers. To maximize the effectiveness of the exhibition, the manager not only picks out the products which have some unique characteristics to attract visitors, but also choose the staff members who have good people skills and communication skills and can make an elaborate and well-informed introduction to satisfy visitors ( Browning \& Adams, 1988). Marketing tries to attain consumers' needs and wants through exchange processes. Marketing activities include market research, product development, distribution, pricing, advertising and training salesperson. These activities are programmed under corporate identity and business goal and achieve a win-win for consumers as well as companies (Philip, 1991). A combination of exhibition and marketing is a powerful method to arouse visitors' interest in products, develop a bond with customers and boost corporate image at a particular exhibition (Zhou, 2008). The participating companies at an exhibition can get background information about the potential visitors. The background information helps them to decide the booth design, like marketing strategies, the location of the booth, the decoration of the booth, DM and free gifts, and activities, to satisfy visitors of different motives (Bello \& Lothia, 1993). Furthermore, exhibition receptionist's marketing skills decide the success of the display, so on-the-job training before the exhibition is a necessary investment (Stanton \& Buskirk, 1987). And process products or services provided by the enterprise, the product can't meet consumer need, but the consumer is through experience. The consumers feel satisfying experience and expectation to desire and demand for the product. So experiential marketing in the exhibition is also important marketing strategy of the exhibitors (Abbott, 1995).

\section{Methodology}

This is a case study of a sporting goods producer. On-site observation and interview were conducted to gather data about their planning and strategies before the exhibition and the moment of the exhibition.

\subsection{Study subjects}

Four Taiwan-based sporting goods producers are the subjects of the study: JOONG CHENN, DYACO, DK CTTY and JOHNSON. The four companies were sampled because they have participated in international sporting goods exhibitions and because their companies have operated at least 10 years. Among them, JOONG CHENN received in-depth interview and a business proposal, made based on the results of the interview, for future international exhibitions. JOONG CHENN has run the business more than 20 years, with 96 partners in Taiwan and abroad, across 56 countries. It also has appeared in international exhibitions for numerous times and claimed to fame in the international markets.

\subsection{Study design and process}

The subjects were solicited through emails or letters. Before the interview, the history and development of these companies were investigated. The interviews were transcribed word for word for data analysis. Based on literature reviews, some propositions were made. An open-ended questionnaire was used in the interview. The interviewees came from the marketing divisions and chief executives. Each interview lasted around one or two hours. The questionnaire consists of 6 aspects: (1) factors considered about the display design, (2) pre-exhibition preparations, (3) during-the-exhibition behavior, (4) post-exhibition assessments, (5) international exhibition experiences, and (6) the determinative factors about the success of a business exhibition. The open-ended questionnaire was conducted for two reasons: the interviewees could elaborately talk about each aspect without guided clues and a detailed written record was made.

\section{Case Study Analysis}

On-site observation and interview were conducted in this case study to gather data to draft propositions.

\subsection{Analysis of observed exhibition}

The following table shows the behavior of four sporting goods producers in terms of different criteria in 2016 Taipei International Sporting Goods show. Similarities and differences between them are also pointed out (in Table 1).

\subsection{Interview data analysis}

The interview was conducted only to JOONG CHENN and aimed to explore the business practices of JOONG CHENN in this industry.

1) Operation Procedure: JOONG CHENN appears in large-scale international exhibitions annually, mainly in the United States, Germany, Mainland and Taiwan. The exhibitions in the United States and Germany focus on boosting corporate image and sales, while the exhibitions in Taiwan and Mainland China focus on technology and machinery. JOONG CHENN consists of R\&D (research and development), sale, customer service and so on. R\&D division is responsible for innovation, sale division promotes products and finds distributors, and custom 


\section{International Journal of Science and Research (IJSR) \\ ISSN (Online): 2319-7064 \\ Index Copernicus Value (2013): 6.14 | Impact Factor (2015): 6.391}

service helps customers solve problems and tackles follow-up services. JOONG CHENN finds new customers in three avenues: (1) contacts at the exhibitions, (2) surfing Internet to find distributors, (3) sending letters to visitors whose contact information is kept in the Taiwan External Trade Development Council (TAITRA) database. All divisions take part in each international exhibition. R\&D develops new products and gets sale division acquainted with new products. Sale division exerts professional skills and eloquent speech to promote products. QC (quality control) division helps customers solve problems immediately they receive customers' complaints. At the exhibition venue, one or two staff members from QC and marketing divisions are always in their presence while sale division takes charge of most stuff. Marketing and QC divisions tour around the exhibition and study other producers' policies and products and the collected information can be used as references for R\&D and sale.

2) Pre-exhibition Preparation: JOONG CHENN decorated the booth of Taipei International Sporting Goods Show with gray and red. Two-thirds of displayed products were the latest versions and the rest were older versions one or two years ago. The best-sellers were placed in the center of the displaying area. Computers, posters and catalogs are necessary tools. JOONG CHENN firmly believed it was high-quality and functional equipment that drew customers and visitors, so they didn't organize any Showgirl performance. The budget spent on the exhibition was around NT $\$ 2.5$ million. The revenue at this exhibition was from NT\$6 to NT\$8 million dollars. To have a well-organized exhibition, all participants received a training to acquire needed information and skills.

3) During-the-Exhibition Behavior: Salespersons first greeted visitors with a radiant smile. Then they patiently explained the operation and function of equipment to visitors and further urged visitors to give it a try. Next, the potential buyers were seated and offered a good bargain about the price or other complimentary gifts. JOONG CHENN noted that high quality, good follow-up service and reasonable price made a deal possible. Marketing staff at the exhibition endeavored to boost corporate image, build brand, regulate the price, find distributors, and promote products. Good service offered by sale and customer service divisions is the key to corporate identity. The price is regulated based on the financial statements released by Finance Ministry, the market price of similar products and the profit the producer wants to earn. At the exhibition, staff members offered adjusted prices depending on the bargain with the buyers. Finding trust-worthy distributors is necessary. Distributors help to deal with old versions. Discounts are offered for three occasions: promoting new versions, high and low seasonal sales. At the exhibition, staff members spent 10 to 15 minutes introducing the new features of new versions and then talked about the ordering policies.

4) Post-exhibition Assessments and Follow-up: JOONG CHENN annually assesses the sale performance of distributors, which decides whether JOONG CHENN will sign a long-term partnership contract with distributors. Distributors have to submit a sale checklist to JOONG CHENN monthly, so the staff in the sale division can have a full picture of customers' needs. For those distributors who maintain a high sale performance, JOONG CHENN will offer a long-term partnership. For those who don't reach the minimum sale amount, JOONG CHENN will help them to boost growth. With greatest sale amount, sale increasing ratio, and loyalty, top ten distributors are awarded with a crystal trophy annually. After the exhibition, assessments about the effectiveness are made instantly. The exhibition location is a great factor about the display scale. For example, at Taipei-based exhibitions, local producers save a lot of travel expense and, therefore, can put on a larger-scale display with much more products. The next day after each exhibition, JOONG CHENN files the contact directory of the exhibition visitors and list useful information collected at the exhibition. Then a staff meeting is convened to spread the information, such as customers' complaints and suggestions, brainstorm how to react to threats and how to keep up with innovation, and come up with new ideas for next exhibitions.

\subsection{Propositions}

Exhibitions enhance the partnership between the producer and its distributors, old or new (Hansen, 1999). At the exhibition, staff members' friendliness, professional knowledge, workload, collaboration, perception of customers' needs and tastes, and communication skills greatly affect the success of the display (Ye \& Zhu, 2009). To make the display successful, JOONG CHENN provided a pre-exhibition training for participating staff. The pre-exhibition focused on the new functions and operation of new versions lest exhibition staff members damage corporate identity because they couldn't answer visitors' questions with professional and fluent explanation. The awkward situation might lower visitors' confidence in the producer and weaken the purchase interest toward products. Also, on-site observation indicated most of visitors are foreign customers. Therefore, receptionists at the exhibition venue have to have good command of English or other foreign languages besides a good knowledge of products themselves. Of course, smiling is another international language.

\section{Proposition 1: Pre-exhibition trainings improve exhibition participants' proficiency.}

The location of the display booth decides the number of visitors and the effectiveness (Wen, 2001). Therefore, the noticeable location of a display booth is more likely to make the display successful (Qiu et al., 2014; Ye \& Zhu, 2009). The observed producer in this study and other popular producers were spotted in the center of the exhibition venue, the most-visited location. Besides, the observed producer covered a vast area and could display a variety of products in a unique design (in Figure. 1 show the booth of four sporting goods companies in 2016 exhibition). No wonder, the producer could create great publicity.

Proposition 2: The fact that a display booth is located in the center of the exhibition venue can empower the display.

Hands-on experience activities are a must for a successful exhibition. In these experience activities, customers not only 


\section{International Journal of Science and Research (IJSR) \\ ISSN (Online): 2319-7064 \\ Index Copernicus Value (2013): 6.14 | Impact Factor (2015): 6.391}

have a chance to know more about the product itself and the service, but also have a direct contact with the product (Schmitt,1999). The direct contact leads to a real-time sensational reaction and an unforgettable pleasant memory (Pine \& Gilmore, 2003; Cordes \& Ibrahim,1999). The on-site observation found that large gym equipment could attract visitors to do hands-on experience and that he exhibition receptionist could offer elaborate explanation to satisfy visitors. Therefore, the communication between the producer and the potential buyers continued.

Proposition 3: Hands-on experience activities facilitate the interaction and communication between the two parties of a deal.

The more popular the products of a producer, the greater publicity it will have (Yao, 2007; Chaudhuri \& Holbrook, 2001). The reason that popular producers display their products at exhibitions is to boost corporate image, maintain publicity, and attract buyers (Wen, 2001; Zeithaml, 1988). The on-site observation in this study noticed that JOONG CHENN, DYACO, DK CTTY and JOHNSON are popular producers in Taiwan and that their long-standing operations help to attract much more buyers. Plus, JOONG CHENN reported that its company had not missed any Taipei-based exhibition because exhibitions helped companies to boost sale performance, upgrade publicity and develop a bond with customers with face-to-face communication. If a certain producer missed a specific exhibition, rumors about its business might negatively affect the subsequent sales.

Proposition 4: A producer's publicity decides the number of visitors appearing at its display booth in an exhibition.

New products are the spotlight of exhibitions (Yao, 2007). New products can lure more exhibition visitors, so advertising and marketing new products at an exhibition can increase the subsequent sale amount (Wen, 2001). $60 \%$ of the exhibition visitors are looking for new products (Hong, 2000). In the on-site observation and interview, JOONG CHENN reported that the main purpose of joining an exhibition was to launch new products. JOONG CHENN added that according to the number of visitors, local or abroad, they could not only predict market share and customers' acceptability but could collect suggestions for improvement through face-to-face and interactional communication. The best displaying place for new products is the center or the entrance to the booth.

\section{Proposition 5: New products are the target for producers and visitors to be present.}

Like advertising, an exhibition can build corporate image and also lure visitors to buy something ((Belizzi \& Lipps, 1984; Smith, 1998). Hence, the design of a display booth at the exhibition is closely associated with the establishment of corporate identity and professional image (Huang, 2009). In addition, the size of a display booth is in proportion to the business scale of a company and the decoration of a display booth boosts Corporate Identity System (CIS) and product characteristics (Yao, 2007). In observation and interview, JOONG CHENN revealed that the exhibition organized arranged display booths according to the displayed products and the size of a display booth. The booth design in this Taipei-based exhibition reflected the characteristics and images the brands desire to set up. JOONG CHENN is a gym equipment producer and was arranged on the specific 4th-floor. The blue print of the display booth was designed by the design division and then recruited woodworking contractor to build the display booth. The display booth was decorated with gray and red, which conveyed diligence and reliability, the work ethics the company has always stuck to. DYACO, DK CTTY and JOHNSON also occupied larger booths and deliberately designed the booths. Clearly, the size of the display booth and its design elaboration were tied to the company's business scale.

Proposition 6: Companies use the scale and design of the display booth to upgrade corporate image.

At the exhibition, finding potential new buyers is more important than just obtaining orders (Wen, 2001). Potential new buyers serve as the opportunity for the increased market share. The greater number of potential new buyers indicates the stronger effectiveness of the display. The increasing potential buyers not only bring in more revenue but also reduce the risk of lose money (Zhu, 2009). In this study, JOONG CHENN did set the priority goal of finding potential new buyers in the Taipei-based exhibition. Before the exhibition, each exhibition receptionist set the number of potential new buyers they anticipated to find. Even though JOONG CHENN had developed a stable relationship with their old customers, these old customers might just maintain the trading amount or go for the end of partnership or other reasons. Thus, finding potential new buyers to expand the business was essential.

Proposition 7: Finding potential new buyers is the priority goal while joining exhibitions.

\section{Discussion and Conclusion}

\subsection{Discussion}

The data, collected in on-site observation and interview, about JOONG CHENN will be analyzed and discussed in terms of three stages: pre-exhibition planning, during-the-exhibition behavior, and post-exhibition assessments and follow-up.

1) Pre-exhibition Planning: To maximize the effectiveness of the exhibition, JOONG CHENN sent out a lot of invitations before the exhibition. They invited old customers to experience new products. They invited distributors to the exhibition for face-to-face communication about the distribution rights and sale policy. They also sent invitations to new potential partners whose contact directory were kept in Taiwan External Trade Development Council (TAITRA) database.

2) During-the-exhibition Behavior: In the Taipei-based exhibition, JOONG CHENN's display booth was located in the middle of the second row. Products of four brands, Fitnex, Body-solid, Steelflex, and Weck, were separately displayed in four sections, which facilitated exhibition receptionists' interpretation in response to visitors' needs. The simplicity of the display booth matched the marketing 


\section{International Journal of Science and Research (IJSR) \\ ISSN (Online): 2319-7064}

Index Copernicus Value (2013): 6.14 | Impact Factor (2015): 6.391

strategy that products themselves, not Showgirl performances, attracted interested visitors. The overall decoration colors were only gray and red, with red brand names against gray walls. No glamorous accessories, but clear, flowing walkways and a variety of products. Reliability, fitness, simplicity and being easy-going were sensed at the venue. TV wall playing the video of explaining the operation and function of products and banners highlighting new products both beckoned interested visitors. All in all, the deliberately designed display booth magically used visual and color effects to boost corporate identity and publicity, which upgraded brand image and value and contributed to successful marketing.

3) As for the way products were placed at the display booth, the award-winning products were at the front most, followed by latest products, still at the front part to draw visitors' attention. On the back wall of the booth were the names of different brands. Under the brand names were the hit products each. Therefore, visitors could have clearer picture of the distinctive features among brands. The award-winning product at the front most was introduced by the video of carefully explaining the operation and innovation. The exhibition activities included new product release, gym equipment display, and free gift sending. The exhibition receptionists knew international etiquette well and possessed fluent foreign language and also had a full knowledge of displayed products. JOONG CHENN also offered room reservation and shuttle service to customers abroad as a token of hospitality. For those customers who couldn't come, JOONG CHENN mailed them the related information and photos in order to give the absent customers a feeling that they were not ignored by JOONG CHENN. All staff wore neat uniforms and identity cards. Five to ten staff members were present at the display booth anytime and ready to offer interpretation. They exchanged business cards with interested visitors, delivered catalogs, and explained the operation and function of products with computer-aided introduction or real machines or even offered hands-on experience activities. At the same time, their interpretation had to pinpoint the advantages of products. They also had to make a brief record about their interaction with visitors and file contact directory for follow-up service or partnership development. The prices of products by JOONG CHENN were decided by the all divisions based on Finance Ministry's financial statements and sensible profits. At the exhibition, the price of a product was basically decided on FOB, but other expenses might be regulated a bit depending on the staff member's influence in the company. Besides, the price at the exhibition was not a firm offer. The final firm offer would be sent out to buyers through email or fax afterwards. Last but not least, a reasonable product warranty accompanied with good follow-up service won customers' trust toward JOONG CHENN.

4) Post-exhibition Assessments and Follow-up: After the exhibition, a lot of things had to be done. (1) JOONG CHENN made an overall assessment in terms of the number of visitors, brand image, market opportunity and competiveness. JOONG CHENN also strove to develop a partnership with potential new buyers. Then new potential buyers would persistently keep track of the number of partners and the sale profits after the exhibition. (2) JOONG CHENN carefully analyzed cost and profits. (3) A staff meeting was convened to evaluate the exhibition and submit suggestions for improvement. (4) A contact directory would be filed according to the data written on the reception record. Potential new buyers might be categorized into several groups for follow-up contact. A gratitude letter was delivered to buyers through e-mail or post mail. Then customers' needs and thoughts which were recorded at the exhibition would be further discussed and be satisfied at follow-up service. Constant contact with customers ensured the stability of the trade or sparked more trade and gain insight into business opportunity.

\subsection{Conclusion}

This study explores how a business company prepares for its display in an international exhibition, what the company does at and after the exhibition to maximize marketing strategies. The data are gathered from an on-site observation of Taipei International Sporting Goods Show and an interview of JOONG CHENN's staff members, a popular sporting goods producer in Taiwan. With data analysis, seven propositions about marketing are made. Pre-exhibition planning, during-the-exhibition behavior, and post-exhibition assessments and follow-up are essential to ensure a successful exhibition. Three findings are found in this study:

1) Pre-exhibition training can improve exhibition receptionists' marketing skills. At the pre-exhibition training, exhibition receptionists have to get acquainted with new products. Their good knowledge of new products helps them to offer professional interpretation and win customers' trust and gratification.

2) The center of the exhibition venue is the best bet for a successful display. The display booth of the study subject, JOONG CHENN, lies in the center of the exhibition venue and can attract much more visitors than other companies at the periphery. What's more, JOONG CHENN's display booth occupies a larger area and is decorated in a unique design. Obviously, popular companies pay a lot of attention to the design of the display booth at an exhibition because the design speaks corporate identity and its characteristics.

3) Hands-on experience activities can facilitate the development of a partnership between two parties of a deal. Large gym equipment is placed at the display booth of the study subject for hands-on experience activities. Visitors can operate the equipment with the aid of exhibition receptionists. The hands-on experience creates a sensational memory on visitors, which breaks the ice and makes further interaction possible.

4) A company's publicity is one of the key draws which attract visitors. Exhibition visitors mostly visit with the booths of high-profile companies. Clearly, it is easier for a high-profile company to attract more visitors than others.

5) New products are the major lure for which both producers and customers are present in the exhibition. A producer which is going to launch a new product can test the waters at the exhibition to see how customers feel about it and predict if the new product will make a hit. Also, if a producer is unable to present a new product at a particularly important exhibition, it might dampen its 


\section{International Journal of Science and Research (IJSR) \\ ISSN (Online): 2319-7064}

Index Copernicus Value (2013): 6.14 | Impact Factor (2015): 6.391

attractiveness and compromise its reputation. Worse still, rumor about its bad business might spread.

6) Companies elaborately highlight their corporate identity in planning exhibitions and designing booths. These companies mentioned in this study occupy bigger booth areas and have well-designed booths. Because the booth design represents corporate image, these companies spare no effort to build their brand and enhance their characteristics.

7) Looking for new customers is a goal companies try to reach while they take part in a business exhibition. These companies mentioned in this study are aimed to find new customers at the exhibition. A company always manages to build new partnerships with new potential customers to expand its business as well as reduce the loss from losing some old customers. As a matter of fact, new customers are the main source of the business profits.

\subsection{Implications and future research}

The findings in this study have made some contributions to the industry and the academic research. First, pre-exhibition training is dispensable for a successful exhibition and makes the exhibition go smoothly. Second, the order to place products and the planning of walk way have to be considered. The design of the display booth has to match corporate identity. The display booth in bright style might attract more visitors. Third, well-trained exhibition receptionist, hands-on experience, new products, bigger area and unique design of the display booth, good interaction with potential new buyers boost the effectiveness of the exhibition. Fourth, follow-up interaction and contact with buyers, old and new, ensure the stability of trade and even expand the business. Finally, a post-exhibition staff meeting can provide suggestions to perfect next exhibitions.

In this study, on-site observation and in-depth interview are conducted to gather data. It is suggested that future researchers may adopt a quantitative methodology, like questionnaire, to paint a fuller picture of how related businesses maximize their marketing effectiveness in Taipei International Sporting Goods Show. This study is a case study of the marketing policies of a participating company at an exhibition. Future research can be focused on comparison between marketing policies adopted by different companies. This study doesn't explore the buying behavior pattern of exhibition visitors, which can be an approach worth further investigating.

\section{References}

[1] Abbott, J., \& Abbott, P. (1995). Psychological and cardiovascular predictors of anesthesia induction, operative and postoperative complications in minor gynecological surgery. British Journal of Clinical Psychology, 34, 613-625.

[2] Belizzi, J.A., \& Lipps, D.J. (1984). Managerial guidelines for trade show effectiveness. Industrial Marketing Management, 13, 49-52.

[3] Bello, D. C., \& Lothia, R. (1993). Improving trade show effectiveness by analyzing attendees. Industrial Marketing Management, 22, 311-318.
[4] Blythe, J. (2010). Trade fairs as communication: A new model. Journal of Business \& Industrial Marketing, 25(10), 57-62

[5] Browning, J. M., \& Adams, R. J. (1988). Trade shows: An effective promotional tool for the small industrial business. Journal of Small Business Management, 26(4), 31-36.

[6] Cavanaugh, S. (1976). Setting of objectives and evaluating the effectiveness of trade show exhibits, Journal of Marketing, 40(10), 100-103.

[7] Chaudhuri, A., \& Holbrook, M. B. (2001). The chain of effects from brand trust and brand affect to brand performance: The role of brand loyalty, Journal of Marketing, 65(2), 81-93.

[8] Chou, Y. M., \& William, T.S.A.I. (2013).The development of MICE and evaluation of MICE education in Taiwan, Yu Da Academic Journal, 35(8), 57-74.

[9] Cordes, K.A., \& Ibrahim, H.M. (1999). Application in recreation and leisure for today and the future. New York, WCB: McGraw-Hill.

[10] Czinkota, M. R., \& Ronkainen, I. A. (1988). International marketing, U.S.A: Dryden Press.

[11]Hansen, K. (1999). Trade show performance: a conceptual framework and its implications for future research. Academy of Marketing Science Review, 8, $1-12$.

[12] Holloway, J. C., Humphreys, C., \& Davidson, R. (2009). Business of tourism. 8th Harlow. Pearson education limited: England.

[13]Hong, M. Q. (2000). How to take the exhibition to sales of the products. Taiwan External Trade Development Council, TAITRA.

[14]Huang, Z. J. (2009). Introduction to the exhibition industry. Taiwan External Trade Development Council, TAITRA.

[15] Jackson Jr, D. W., Keith, J. E., \& Burdick, R. K. (1987). The relative importance of various promotional elements in different industrial purchase situations. Journal of Advertising, 16(4), 25-33.

[16]Philip, K. (1991). Marketing management-analysis, planning, implementation, and control. 7th ed, Prentice-Hall.

[17]Pine II, B. J, \& Gilmore, J. H. (2003). The experience economy: Work is theatre and every business a stage, Cambridge, MA: Harvard Business School Press.

[18] Qiu, C. Y., Chen, Y. H., You, C. K., Zhang, W. Y., Lin, Y. C., \& Xu, X. F. (2014). Key success factors on promoting the MICE in Taiwan. Management Information Computing, 3(1), 99-119.

[19] Rutherford, D. G. (1990). Introduction to the conventions, expositions and meetings industry. New York: Van Nostrand Reinhold.

[20] Schmitt, B. (1999). Experiential marketing. Journal of Marketing Management, 15(1-3), 53-67.

[21] Smith, T.M. (1998). The effectiveness of trade show efforts for exhibitors of wood-working machinery. A Thesis in Forest Resources, Graduate School, School of Forest Resources, Pennsylvania State University.

[22] Spiller, J. (2002) History of convention tourism, in Weber, K. and Chon, K. (Eds), Convention Tourism: 


\section{International Journal of Science and Research (IJSR) \\ ISSN (Online): 2319-7064 \\ Index Copernicus Value (2013): 6.14 | Impact Factor (2015): 6.391}

International Research and Industry Perspectives. The Haworth Press, New York, NY, 3-19.

[23] Stanton, W. J., \& Buskirk, R. H. (1987). Management of the sales force, 7th, Homewood, IL:Richard D. Irwin, Inc.

[24] Wen, Y. C. (2001). How to participate the exhibitions in abroad? Taiwan External Trade Development Council, TAITRA.

[25] Yang, L. T., \& Gu, Z. (2012). Capacity optimization analysis for the MICE industry in Las Vegas. International Journal of Contemporary Hospitality Management, 24(2), 335-349.

[26] Yang, M. X., \& Lin, Q. L. (2015). A study of information exhibitors' function requirements on applications. Journal of Ghungchou, 93-108.

[27] Yao, W. Y. (2007). Exhibition marketing bible. China Productivity Center, CPC. Taipei.

[28] Ye, T. M., \& Zhu, M. J. (2009). Meeting and exhibition management. Taiwan External Trade Development Council, TAITRA.

[29]Zeithaml, V. A. (1988). Consumer perception of price, quality andvalue Ameans-endmodel and synthesis of evidence. Journal of Marketing, 52, 2-22.

[30]Zhou, Y. Y. (2008). Marketing strategies and tips of high performance exhibition: prepare exhibitors for the best performance. Monthly Trade Journal, 201, 22-31.
[31]Zhu, J. Y. (2009). Exhibition planning. Taiwan External Trade Development Council, TAITRA.

\section{Author Profile}

Yen-Hui Lin is a director of the department at National Taichung Special Education School for The Hearing Impaired. She is a Doctoral Candidate and major business management, strategic human resource management, and management accounting in the Graduate School of Human Resource Management of National Changhua University of Education (Taiwan).

Yi-Ju Wang is associate professor of Department of Business Administration, Overseas Chinese University. She received her Ph.D. in Department of Applied Economics Completeness University of Madrid(Spain). Her research concerns include marketing management, international business, Regional Economic Integration.

\section{Appendix}

Table 1: The difference analysis of four sporting goods companies in 2016 exhibition

\begin{tabular}{|c|c|c|c|c|}
\hline Item Company & JOONG CHENN & $D Y A C O$ & JOHNSON & $D K C T T Y$ \\
\hline Establish & 1980 & 1990 & 1975 & 1987 \\
\hline Brand & $\begin{array}{l}\text { Weck, Body-Solid, Steelfex, } \\
\text { Fitnex }\end{array}$ & Spirit & $\begin{array}{c}\text { Johnson, Matrix, Vision } \\
\text { Fitness, Horizon Fitness, } \\
\text { Kyoyama } \\
\end{array}$ & Gazzelle Edge, Dkfitness \\
\hline Product varieties & $\begin{array}{l}\text { Workout vehicle, treadmill, } \\
\text { multi-use workout machine, } \\
\text { weight trainer, revolving } \\
\text { fitness chair, push-up bench, } \\
\text { dumbbell }\end{array}$ & $\begin{array}{l}\text { Workout vehicle, treadmill, } \\
\text { elliptical trainer, exercise } \\
\text { bike, dumbbell, rower, shake } \\
\text { weight, fishing rod }\end{array}$ & $\begin{array}{l}\text { Workout vehicle, rower, } \\
\text { treadmill, multi-use } \\
\text { workout machine, weight } \\
\text { trainer, stepper, massage } \\
\text { chair }\end{array}$ & $\begin{array}{l}\text { Treadmill, golf cart, multi-use } \\
\text { workout machine, stepper, tennis } \\
\text { ball machine, workout vehicle, } \\
\text { massage chair }\end{array}$ \\
\hline $\begin{array}{l}\text { Marketing } \\
\text { distributors }\end{array}$ & $\begin{array}{c}\text { Asia, Europe, North America } \\
\text { and more } \\
\text { Mainly Europe and North } \\
\text { America }\end{array}$ & $\begin{array}{c}\text { Asia, Europe, North America } \\
\text { and more } \\
\text { Mainly Europe and North } \\
\text { America }\end{array}$ & $\begin{array}{c}\text { Asia, Europe, North } \\
\text { America and more } \\
\text { Mainly Europe and North } \\
\text { America }\end{array}$ & $\begin{array}{c}\text { Asia, America, Europe, Africa, } \\
\text { Oceania } \\
\text { Mainly Europe and Asia }\end{array}$ \\
\hline Business behavior & B to B & $\mathrm{B}$ to $\mathrm{B} / \mathrm{B}$ to $\mathrm{C}$ & $\mathrm{B}$ to $\mathrm{B} / \mathrm{B}$ to $\mathrm{C}$ & $\mathrm{B}$ to $\mathrm{B} / \mathrm{B}$ to $\mathrm{C}$ \\
\hline Production model & OEM / ODM / OBM & OEM & OBM / ODM & OEM / ODM \\
\hline Booth size & 40Units( $3 \mathrm{M} * 3 \mathrm{M})$ & 48Units( $3 \mathrm{M} * 3 \mathrm{M})$ & 48Units( $3 \mathrm{M} * 3 \mathrm{M})$ & 49Units( $3 \mathrm{M} * 3 \mathrm{M})$ \\
\hline Booth decoration & $\begin{array}{c}\text { Designed with red, gray and } \\
\text { black, with the trademarks of } \\
\text { four brands hanging above }\end{array}$ & $\begin{array}{l}\text { Designed with bright yellow, } \\
\text { black and white, with an open } \\
\text { space, a stage in the center, } \\
\text { two entrances inviting visitors }\end{array}$ & $\begin{array}{c}\text { Designed just with gray, } \\
\text { flowing space arrangement } \\
\text { with an electronic display } \\
\text { board showing new } \\
\text { products }\end{array}$ & $\begin{array}{l}\text { Designed with black and white, with } \\
\text { a closed rectangle space, accessed } \\
\text { just by one arch, the brand } \\
\text { trademarks against purple } \\
\text { background, a reception room on the } \\
\text { 2nd floor } \\
\end{array}$ \\
\hline $\begin{array}{l}\text { Exhibition } \\
\text { Product }\end{array}$ & $\begin{array}{c}\text { Workout vehicle, treadmill, } \\
\text { multi-use workout machine, } \\
\text { weight trainer, revolving } \\
\text { fitness chair, push-up bench, } \\
\text { dumbbell }\end{array}$ & $\begin{array}{c}\text { Workout vehicle, treadmill, } \\
\text { elliptical trainer, exercise } \\
\text { bike, dumbbell, rower, shake } \\
\text { weight, fishing rod }\end{array}$ & $\begin{array}{c}\text { Workout vehicle, rower, } \\
\text { treadmill, multi-use } \\
\text { workout machine, weight } \\
\text { trainer, stepper, massage } \\
\text { chair } \\
\end{array}$ & $\begin{array}{c}\text { Treadmill, golf cart, multi-use } \\
\text { workout machine, stepper, tennis } \\
\text { ball machine, workout vehicle, } \\
\text { massage chair }\end{array}$ \\
\hline Display design & $\begin{array}{c}\text { Four brands spreading in four } \\
\text { separate areas, with new } \\
\text { products at the entrance }\end{array}$ & $\begin{array}{c}\text { New products and the } \\
\text { best-sellers at the entrance, } \\
\text { with a set of table and chairs } \\
\text { for visitors inside }\end{array}$ & $\begin{array}{c}\text { Products classified for } \\
\text { places: home, professional, } \\
\text { and school/community, } \\
\text { with the latest products } \\
\text { introduced with video at the } \\
\text { entrance }\end{array}$ & $\begin{array}{c}\text { Products and an electronic display } \\
\text { board placed on the green mats } \\
\text { outside the booth }\end{array}$ \\
\hline
\end{tabular}

Volume 5 Issue 6, June 2016 www.ijsr.net 


\section{International Journal of Science and Research (IJSR) \\ ISSN (Online): 2319-7064}

Index Copernicus Value (2013): 6.14 | Impact Factor (2015): 6.391

\begin{tabular}{|c|c|c|c|c|}
\hline $\begin{array}{l}\text { During-the- } \\
\text { exhibition }\end{array}$ & $\begin{array}{l}\text { Inviting visitors to use new } \\
\text { products and sending out free } \\
\text { gifts with the brand logo }\end{array}$ & $\begin{array}{l}\text { Inviting visitors to use new } \\
\text { products and attracting } \\
\text { visitors with performances, } \\
\text { games and free gifts }\end{array}$ & $\begin{array}{c}\text { Inviting visitors to use } \\
\text { products while listening to } \\
\text { video instructions }\end{array}$ & $\begin{array}{c}\text { Placing products on a small stage, } \\
\text { Showgirl demonstrating how to use } \\
\text { the products, accompanied with } \\
\text { video introductions }\end{array}$ \\
\hline $\begin{array}{l}\text { Catalog } \\
\text { distribution }\end{array}$ & $\begin{array}{c}\text { Interested visitors invited to sit } \\
\text { at the reception table and given } \\
\text { related catalog }\end{array}$ & \begin{tabular}{|} 
Using music and dance to \\
round up visitors, while \\
Showgirl demonstrating \\
products, DM sent out to the \\
audience \\
\end{tabular} & $\begin{array}{c}\text { Interested visitors invited to } \\
\text { sit at the reception table and } \\
\text { given related catalog }\end{array}$ & $\begin{array}{l}\text { First introducing the operation and } \\
\text { function of products, then sending } \\
\text { out the catalog to potential buyers }\end{array}$ \\
\hline Receptionists & $\begin{array}{l}12 \text { people, with the manager } \\
\text { wearing more formal and the } \\
\text { rest in black T-shirt and } \\
\text { trousers }\end{array}$ & $\begin{array}{c}\text { 12-15 people, men with black } \\
\text { T-shirt, and women with } \\
\text { white T-shirt }\end{array}$ & $\begin{array}{c}15-20 \text { people, with the } \\
\text { manager wearing a suit and } \\
\text { the rest wearing red-collar } \\
\text { white T-shirt and khaki } \\
\text { trousers }\end{array}$ & $\begin{array}{c}13-15 \text { people, wearing orange } \\
\text { T-shirt with black collar. Showgirl } \\
\text { wearing pink vest and white } \\
\text { mini-skirt }\end{array}$ \\
\hline Service & $\begin{array}{c}\text { Smiling receptionists shaking } \\
\text { hands with visitors or giving a } \\
\text { business card and offering } \\
\text { further details at the reception } \\
\text { table }\end{array}$ & $\begin{array}{c}\text { Receptionists explaining the } \\
\text { operation and function of gym } \\
\text { equipment to interested } \\
\text { visitors and then introducing } \\
\text { other products and offering } \\
\text { further details at the reception } \\
\text { table }\end{array}$ & $\begin{array}{c}\text { Friendly receptionists } \\
\text { explaining the operation and } \\
\text { function of products and } \\
\text { offering further information } \\
\text { at the reception table }\end{array}$ & $\begin{array}{l}\text { Showgirl demonstrating products } \\
\text { and receptionists explaining the } \\
\text { operation of products and inviting } \\
\text { interested visitors to the } 2^{\text {nd }} \text {-floor } \\
\text { reception room for further details }\end{array}$ \\
\hline
\end{tabular}

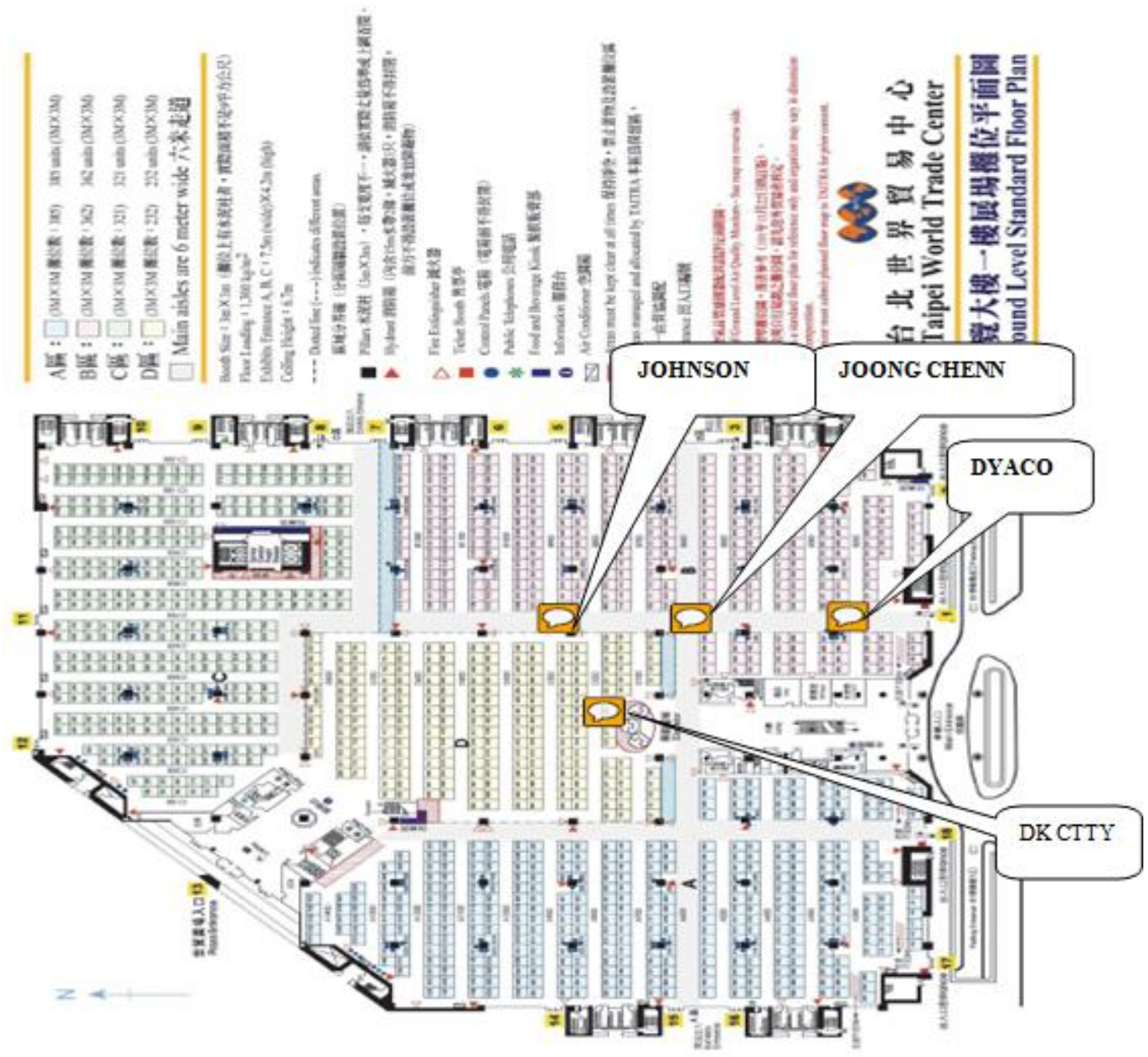

Figure 1: The booth of four sporting goods companies in 2016 exhibition

\section{Volume 5 Issue 6, June 2016 www.ijsr.net}

